\title{
Access to Finance, Technology Investments and Exporting Decisions of Indian Services Firms
}

Check for updates

\section{Shubin Yang ${ }^{1} \cdot$ Chris Milner $^{2} \cdot$ Sandra Lancheros $^{3}$ (D) $\cdot$ Saileshsingh Gunessee ${ }^{4}$}

Published online: 15 July 2020

(C) The Author(s) 2020

\begin{abstract}
This study provides fresh empirical evidence on the influence of various financing sources on firms' technology investments and exporting decisions using a panel of firms from the service sector in India during the period 1999-2010. Allowing both activities to be jointly determined, our results show that the source of finance matters for exporting and investing in technology. Moreover, the importance of different types of finance varies across industries in the service sector. Overall, we find that internal funds and non-conventional sources of finance play an important role for exporting and investing in technology in both modern and traditional services. However, funding from conventional financial markets exerts divergent effects across service industries: while traditional service firms use resources from the banking sector to fund their technological investments, firms in the modern service sector rely more on funds raised through equity markets to support their exporting and technological efforts. These results contribute to the academic literature and policy debate on the importance of financial mechanisms to promote firms' strategic investment decisions.
\end{abstract}

Keywords Financing sources · Technology investment · Exports · Service firms

\section{Introduction}

Technology investment and exporting have been commonly associated with manufacturing firms, while their importance for service firms have received much less

Sandra Lancheros

S.P.Lancherostorres@Leeds.ac.uk

1 School of Economics and Business Administration, Central China Normal University, Wuhan 430079, China

2 School of Economics, University of Nottingham, Nottingham NG7 2RD, UK

3 Leeds University Business School, University of Leeds, Leeds LS2 9JT, UK

4 Nottingham University Business School China, University of Nottingham Ningbo China, Ningbo 315100, China 
attention in the literature. A reason for this is that traditionally international trade has been mainly dominated by manufactured goods, while services have been largely regarded to be less technological intensive and non-tradable (Francois and Hoekman, 2010). In recent decades, however, the importance of services in promoting growth and boosting new technologies has been increasingly recognised given their expanding share in economic activity. Yet, despite the growing magnitude and importance of technology investment and international trade in services, we know very little about the factors enabling services firms to invest in technology and exporting. In particular, the role of finance to support these investments has been largely underexplored in the literature. This contrasts with a rich body of work for the manufacturing sector, which has recognized the crucial importance of finance to support firms exporting and technological investments. ${ }^{1}$

Moreover, the extant (small) literature examining the role of finance on exporting or investing in technology amongst service firms has failed to consider the potential heterogeneous effects of different financing sources to fund these activities. ${ }^{2}$ This paper contributes to fill this gap by examining for the first time the role of a wide array of financial options available to Indian service firms to fund their exports and technology investments. As pointed out by Girma and Vencappa (2014), different forms of finance exhibit different properties, in terms of maturity, degree of formality, and nature. Hence, we argue that it is likely that diverse financial options might have heterogeneous effects on firms' investment decisions. For example, exporting and investing in technology entail higher informational and other market failure problems than other forms of fixed investments due to their higher levels of uncertainty and lack of collateral values, which exacerbates the barriers to obtain conventional external funding such as bank borrowing and equity finance. These barriers are likely to be more pronounced amongst service firms for which assets and outputs are more intangible in nature, making it harder to use them as collateral when seeking for external finance (Silva and Carreira, 2016). As market imperfections are stronger in developing countries, it is likely that firms in these countries rely more on internal funds and/or unconventional sources of finance to fund their investment opportunities than their counterparts in the developed world. Understanding which financial choices are more conducive for exporting and technology investments is therefore crucial for an adequate design and implementation of technological and international business policies, especially in developing countries with stronger market failures and less developed financial systems.

The theoretical underpinnings of our empirical analysis are connected to several strands of the literature. First our work is informed by recent theoretical models in international economics that have incorporated financial factors into the Melitz model (Melitz, 2003) of international trade with heterogeneous firms (i.e. Chaney, 2016;

\footnotetext{
${ }^{1}$ See Wagner (2014) and Wagner, J. (2019) for an extensive survey of the empirical literature on finance and exports; and Kerr and Nanda (2015) for a systematic review of the literature on the role of finance for innovation and technology investments.

${ }^{2}$ Some of the few studies evaluating the role of finance for technological investments amongst service firms include Sirilli and Evangelista (1998) for Italy; Canepa and Stoneman (2007) for UK; and Gorodnichenko and Schnitzer (2013) for 27 transition countries. They all show that finance is an important factor supporting these investments. By contrast, the small literature examining the importance of finance for firms' exporting behaviour in the service sector has suggested a modest or insignificant role for financial factors in export market participation (i.e. Lancheros and Demirel, 2012; Wagner, 2019).
} 
Manova, 2013). ${ }^{3}$ These models have formalized the widespread notion that finance is an important determinant of firms' exporting behaviour due to the elevated sunk cost of entering foreign markets through exports, as well as the high fixed costs and risks associated to remaining in the export market. While a large empirical literature has been devoted to examining the importance of financial constraints for export market participation of manufacturing firms, the empirical literature on the role of finance for exporting services is still scarce.

Our work also builds an extensive theoretical and empirical literature on the importance of finance for innovation and technological investments (i.e. Hall and Lerner, 2010; Ayyagari et al., 2011; Aghion et al., 2012; Brown et al., 2012; Kerr and Nanda, 2015). From a theoretical perspective, innovation and technological investments are subject to important market frictions, which limit the ability of firms to secure financial resources to fund these activities. ${ }^{4}$ In a world with such market frictions the source of finance becomes an important factor shaping firms' innovation and technological activities (Kerr and Nanda, 2015). ${ }^{5}$ While previous studies have focused on examining one or two types of finance (i.e. equity versus debt) or aggregating different sources of finance (i.e. internal versus external finance), we consider a wider range of financing sources used by service firms to fund their technological investments.

Methodologically, our analysis builds on recent theoretical and empirical works in the field of international economics; modelling the interdependence between exporting and technology investments in the manufacturing sector (i.e. Costantini and Melitz, 2007; Aw et al., 2007, 2008, 2011; Atkeson and Burstein, 2010; Lileeva and Trefler, 2010; Bustos, 2011). ${ }^{6}$ Following these works, in our empirical analysis we jointly estimate the decision to export and invest in technology to allow for potential interdependences between these activities in the service sector. This potential complementarity remains unclear in the service literature. To our knowledge only Altomonte et al. (2015) and Máñez et al. (2014) have evaluated the role of financial factors in the simultaneous relationship between exporting and investing in technology using data for European manufacturing firms. ${ }^{7}$ The main focus of these papers is, however, on whether firms are financially constrained to undertake these activities,

\footnotetext{
${ }^{3}$ A synopsis of these theoretical frameworks can be found in Egger and Kesina (2013) and Minetti and Zhu (2011).

${ }^{4}$ These frictions arise from the inherently uncertain nature of such investments as well as issues of asymmetric information, moral hazard, and lack of collateral values, amongst others.

5 Thus, for example, early literature on finance and innovation pointed out the importance of internal sources of finances, as well as, funding raised through external equity markets to fund innovation and technological projects, neglecting the role of bank lending to support these activities (Brown, Fazzari, and Petersen, 2009). However, more recent studies have emphasised the importance of borrowing from banks to support innovation and technology investments (Kerr and Nanda, 2015).

${ }^{6}$ For example, Lileeva and Trefler (2010) show that improved access to foreign markets encourages firms to simultaneously export and invest in raising productivity. Aw et al. (2011) develop a dynamic structural model of a producer's decision to invest in R\&D and export, and estimate this model using plant-level data from the Taiwanese electronics industry. They find a complex set of interactions between R\&D, exporting and productivity.

${ }^{7}$ Mancusi et al. (2018) is another related study (focused on manufacturing firms) which evaluates the effect of the intensity of the bank-firm relationship on a firm's exporting behavior, allowing innovation to be an endogenous determinant of exports.
} 
rather than on investigating the role of a wide range of financing sources available to firms to fund their investment opportunities, which is the main focus of this paper. ${ }^{8}$

By considering a broad set of financial options available to firms, we also contribute to a small but growing literature that emphasises the importance of different financing sources for firms' growth in emerging markets (i.e. Allen et al. 2012; Girma and Vencappa, 2014; Du and Girma, 2012). However, this literature remains silent about the relative importance of different types finance for diverse forms of firm-level investments. This paper contributes to filling this gap by examining for the first time the role of the source of finance for exporting and investing in technology, two major growth-led investment decisions.

In this paper we distinguish between different sources of finance available to Indian service firms to support their exporting and technological investments. Thus, besides examining firms' internal funds, we also consider the importance of external funding from 'conventional sources' (i.e. resources from the banking system and equity markets); as well as other 'non-conventional sources', including loans from promoters, and intercorporate loans, amongst others. We argue that ignoring the importance of different financing options to support firms' investment opportunities might provide an incomplete and inaccurate picture of the role of finance for exporting and investing in technology. This potential omission is likely to be more misleading in the context of developing countries, where conventional forms of finance, such as debt and equity, are less readily available to firms than is the case of developed countries with more mature financial systems.

We examine the role of financial sources on firms' exporting and technology investment decisions using a panel of firms from the Indian services sector during 1999-2010. India is a particularly interesting case to analyse the interlinkage between different financial choices, and firms' exports and technology investment decisions. After decades of strong trade protectionism, excessive banking regulations, and high illiquidity of its equity market, India underwent major adjustment reforms in the 1990s (including the opening up of the economy and the liberalisation and development of its financial sector), which brought substantial increases in international trade and the expansion of financial resources available to firms, in the form of banking credit, and equity finance from stock markets. However, despite having one of the most advanced and well developed financial systems amongst developing nations, India is still cursed with weak legal institutions and ineffective investment protection, which has limited the scope of the financial market to operate at its maximum potential (Allen et al., 2012). The peculiarity of having a modern financial sector combined with poor legal institutions, makes India a particularly interesting laboratory to evaluate the role of a wide range of financial options available to firms to fund their investment opportunities. We are interested in understanding how Indian service firms funded the unprecedented surge of exports and technological investments that occurred during first decade of the post-reform period. ${ }^{9}$

\footnotetext{
${ }^{8}$ Máñez et al. (2014) use cash flow to measure internal financial constraints and the cost of firms' new longterm debt to measure the external financial constraint, while Altomonte et al. (2015) employ bank credit rationing to proxy for financing constraints.

${ }^{9}$ As documented by Sahoo and Dash (2017), the share of service exports in Indian GDP increased from a modest $1.4 \%$ in $1990-91$ to $7.7 \%$ in 2011-12, and on a global scale, Indian service exports grew about 6 times faster than the world's total exports during the same period. This expansion of services exports was supported by increasing technological investments, such as R\&D and improvements in information and communication technologies, which reduced firms' barriers to accessing foreign markets.
} 
Given the heterogeneous nature of the service sector in India, in our empirical analysis we distinguish between 'modern services' (such as software, business and telecommunication services) and 'traditional services' (such as travel and transportation). As pointed by Sahoo and Dash (2017), the wide range of activities encompassing the service sector imply that service firms operate differently and face diverse levels of trade barriers. Understanding whether firms' reliance on various sources of finance for exporting and investing in technology varies across service industries is therefore relevant from an academic and public policy perspective. To our knowledge only Sahoo and Dash (2017) have examined the determinants of service exports in the modern and traditional sector in India from a macroeconomic perspective.

We contribute to the existing literature in a number of ways. First, we examine the role of a wide range of financing sources used by firms, including both internal and external sources, while previous literature had usually considered only one or two types of finance, ignoring other important financing sources to support firms' exports and technological investments. Second, we focus on the largely neglected service sector, where the levels of uncertainty and lack of collateral are likely to be more pronounced than those in the manufacturing sector, intensifying the barriers to access conventional sources of finances and increasing the potential need for internal and unconventional financing sources. Third, we distinguish between modern and traditional services, a distinction that has not been explored in previous firm-level studies. As discussed before, the different nature and trade barriers faced by different types of services makes this distinction relevant from an academic and policy perspective. This distinction is particularly relevant in India given the increasing prominent role of its modern service sector in GDP and international trade (Sahoo and Dash, 2017). Fourth, we investigate these issues in the context of India, which is notable for the development of its services sector and modern financial sector, yet with a weak legal institutional setting and ineffective investment protection obstructing the well-functioning of its financial market. The study of technology investment and exporting services has important policy implications not only for India, but also for other developing countries with similar financial market structures and institutional development, where conventional and unconventional sources of finance co-exist. Finally, from a methodological perspective we allow for the potential simultaneity in firms' decision to invest in technology and enter foreign markets via exports. As mentioned before, the interaction between firms' exports and their technological efforts has been studied for manufacturing firms, but has been neglected for service firms. Yet, technological investments are also important for service firms to connect to foreign markets and increase their export market participation (Sahoo and Dash, 2017).

Our results, which remain consistent to several robustness tests, show that consistent with previous studies for the manufacturing sector, the decisions to export and invest in technology are also jointly determined by Indian service firms. Also, in line with our expectations, Indian service firms rely more heavily on internal finance and other sources of finance to fund their exporting and technological investments, whereas conventional sources of finance, such as bank lending and equity finance, play a more limited role despite the important liberalization and development of Indian financial sector. In particular, our findings show that equity finance is yet to play a more prominent role to support the investment opportunities of Indian service firms, such as exporting and technological investments. From an academic perspective, our 
findings point to the need for considering the availability of diverse financial options available to firms in developing countries when investigating the role of finance for firms' behaviour. From a policy perspective, our results make a case for developing countries to strengthening their legal institutions alongside the liberalization of their financial sector to allow firms to benefit from conventional sources of finance, such as equity capital which are especially suited to fund highly risky activities, such as technology investments and exporting.

The remainder of the paper is organised as follows. Section 2 presents the empirical framework. Section 3 discusses the data and measurement issues. The empirical results are presented in Section 4, and the conclusions are set out in Section 5.

\section{Empirical Framework}

\subsection{The Empirical Model}

As mentioned in the introduction, the aim of this paper is to evaluate the role of different financing sources for exporting and technology investments amongst Indian service firms. As stated previously, recent theoretical developments in international economics have emphasised that firms' technology investments and exporting decisions are mutually determined, and this complementarity has received ample empirical support using firm-level data from the manufacturing sector. To allow for this potential simultaneity between exporting $(E X)$ and investing in technology (Tech) amongst service firms, we employ a dynamic bivariate Probit model, following the framework of Aw et al. (2007) and (2011), and Máñez et al. (2014) as follows:

$$
\begin{gathered}
\operatorname{Tech}_{i t}^{*}=X_{i, t-1}^{\prime} a+\varepsilon r_{i t} \\
E X_{i t}^{*}=X_{i, t-1}^{\prime} b+\varepsilon x_{i t}
\end{gathered}
$$

The two outcomes are determined by the unobserved latent variables $T e c h_{i t}^{*}$ and $E X_{i t}^{*}$; where $X_{i, t-1}^{\prime}$ is a vector of regressors; and $\varepsilon r_{i t}$ and $\varepsilon x_{i t}$ are the corresponding error terms, which are jointly and normally distributed with mean equal to zero, variance equal to 1 , and correlation equal to $\rho$.

The key difference between estimating our two equations simultaneously using a bivariate Probit model and estimating them separately using the standard univariate Probit estimator is that, in addition to estimating the common set of parameters in both equations, the bivariate Probit estimations provide an estimate of the interrelatedness of exporting and investing in technology. This relatedness occurs via the conditional tetrachoric correlation of the error terms, $\rho$ (Greene 2012; Filippini et al., 2018). ${ }^{10}$

\footnotetext{
${ }^{10}$ The usual Pearson correlation measure widely used to quantify the association between two continuous variables is inappropriate to quantify the correlation between our exporting and technology investment variables given their binary nature. One of the main advantages of estimating the model using a bivariate probit approach is to obtain a more accurate measure of the correlation between the binary dependent variables under analysis. As pointed by Greene (2012), the conditional tetrachoric correlation ( $\rho$ ) measures the "correlation that would be measured between the underlying continuous variables if they could be observed".
} 
Thus, although the simultaneous estimation does not affect the consistency of the univariate Probit estimates, the bivariate Probit estimation has the advantage of providing the correlation between exporting and investing in technology, as captured by $\rho$. If exporting and investing in technology are jointly determined, the correlation between these error terms is non-zero. In the absence of such correlation (i.e. under the null hypothesis that $\rho$ equals to zero), the model consists of two independent univariate Probit equations, which can be estimated separately, without efficiency loses. ${ }^{11}$

We define exporting $(E X)$ and investing in technology (Tech) as two binary activities as follows are:

$$
\begin{gathered}
\text { Tech }_{i t}=\left\{\begin{array}{cc}
1 & \text { if } \text { Tech }_{i t}^{*}>0 \\
0 & \text { if } \text { Tech }_{i t}^{*} \leq 0
\end{array}\right. \\
E X_{i t}=\left\{\begin{array}{cc}
1 & \text { if } E X_{i t}^{*}>0 \\
0 & \text { if } E X_{i t}^{*} \leq 0
\end{array}\right.
\end{gathered}
$$

Thus, we estimate the following dynamic bivariate Probit model:

$$
\begin{aligned}
& \text { Tech }_{i t}=\left\{\begin{array}{cc}
1 & \text { if } a_{1} \text { Tech }_{i, t-1}+a_{2} E X_{i, t-1}+a_{3} \text { FIN }_{i t-1}+a_{4} Z_{i t-1}+a_{t}+a_{j}+\varepsilon r_{i t}>0 \\
0 & \text { otherwise }
\end{array}\right. \\
& E X_{i t}= \begin{cases}1 & \text { if } b_{1} E X_{i, t-1}+b_{2} \text { Tech }_{i, t-1}+b_{3} \text { FIN }_{i t-1}+b_{4} Z_{i t-1}+b_{t}+b_{j}+\varepsilon x_{i t}>0 \\
0 & \text { otherwise }\end{cases}
\end{aligned}
$$

$$
(\varepsilon r, \varepsilon x) \sim \text { Bivariate Normal }\left[\left(\begin{array}{l}
0 \\
0
\end{array},\left(\begin{array}{ll}
1 & \rho \\
\rho & 1
\end{array}\right)\right)\right]
$$

Where $E X_{i t}$ is an indicator variable that takes the value of 1 for exporting firms (zero otherwise); and $T e c h_{i t}$ is also a dummy variable equal to 1 for firms that invest in technology (zero otherwise). Prior studies examining exports and technology investments by manufacturing firms have mostly used Research \& Development (R\&D) expenditure as a measure of firms' technological efforts. Unlike these studies, in this paper we employ a broader measure of technology investment, which includes R\&D expenditure; royalty, technical know-how and license fees, and new software and computer additions. The use of a wider measure of technology investments is in line

\footnotetext{
${ }^{11}$ See Greene (2012) for more technical details of the bivariate Probit approach.
} 
with the fact that, although some services have high technological capabilities, R\&D is still an activity mainly confined to manufacturing firms. ${ }^{12}$ For service firms, technology investments are determined by specific characteristics that are highly relevant to the sector, such as the close interaction between production and consumption (or coterminality); the high information-intangible content of services products and processes; the important role played by human resources as a key competitive factor; and the critical importance of organisational factors for firms' performance (Sirilli and Evangelista, 1998). Thus, we believe that our combined measure of technology investments captures better the characteristics and technological efforts of firms in the service sector, than the simple use of R\&D expenditure.

The variables $T e c h_{i, t-1}$ and $E X_{i, t-1}$ are dummy variables indicating whether a firm invests in technology and/or exports, respectively, in year $t-1$. We include these variables in our empirical estimation to account for the well-known dynamic and persistent nature of exporting and investing in technology (as captured by the coefficients $a_{1}$ and $b_{1}$ ); as well as the likely interrelationships between these two decisions (as measured by the coefficients $a_{2}$ and $b_{2}$ ). Given that exporters tend to invest in technology to assimilate and utilise the new knowledge they gain from exporting (Aw et al., 2007), and that technology investments improve productivity and facilitate exporting in manufacturing, we assume that these relationships are also valid for services firms. We therefore expect both $a_{2}$ and $b_{2}$ to be positive.

$F I N_{i t-1}$ is a vector of financing sources variables, comprising firms' internal funds (measured by firms' retained profits), external finance from: i) the banking system, in the form of loans from banks and financial institutions, ii) funds raised from equity markets, measured by firms' equity capital, and financial funds from other financial sources, including loans from promoters, intercorporate loans, foreign currency borrowing, and trade credits amongst others. ${ }^{13}$ These financial indicators are measured in natural logarithms and lagged one period to ameliorate any potential reverse causality between financing sources and technology investment /exporting. The literature shows that financing is an important factor in determining service firms' technology investments (Sirilli and Evangelista, 1998; Canepa and Stoneman, 2007), therefore, we expect at least one of the coefficients of our financing source variables to be positive. Likewise, given that entering a foreign market involves costs such as market research, setting up distributional networks and promotional activities, we also expect to find some positive associations between our financing source variables and exporting. The main interest of this paper is to identify what type(s) of funding that are more conducive for exporting and investing in technology in the service sector.

$Z_{i t-1}$ is a vector of control variables, identified in the literature as important determinants of firms' decisions about exporting and investing in technology. These control variables include the age and size of the firm, its ownership status, and the firm's international experience as an importer of services and/or capital goods, given that the recent literature has found positive effects of access to foreign inputs on firm exporting or productivity (Bas, 2012; Feng et al., 2016; Gullstrand et al., 2016; Foster-McGregor

\footnotetext{
${ }^{12}$ In our dataset, only $1.3 \%$ of service firms are engaged in R\&D investment.

13 To be more precise, the sources of finance included in this category are hire purchase loans, deferred credit, debentures and bonds, borrowings syndicated across banks \& institutions, loans from promoters, directors and shareholders, inter-corporate loans, commercial papers, fixed deposits, foreign currency borrowings, other borrowings and trade credits.
} 
et al., 2016). ${ }^{14}$ To account for time and industry fixed effects we include year $\left(a_{t}\right.$ and $\left.b_{t}\right)$ and industry $\left(\mathrm{a}_{\mathrm{j}}\right.$ and $\left.\mathrm{b}_{\mathrm{j}}\right)$ dummy variables. Finally, $\varepsilon x_{i t}$ and $\varepsilon r_{i t}$ are error terms, with a correlation parameter equal to $\rho$. Table 1 provides the precise definition of the variables used in our analysis.

\subsection{Empirical Strategy}

We estimate eqs. (3a) and (3b) simultaneously by maximum likelihood (ML). An econometric problem facing the dynamic model is the potential correlation between past technology investment/export status and unobserved heterogeneity. We address this problem following the approach of Wooldridge (2005) and Lancheros and Demirel (2012) by modelling firm's unobserved heterogeneity as a linear function of the initial values of the explanatory variables. In other words, we include the initial values of the explanatory variables as additional regressors. This approach enables us to strip out any unobserved advantages enjoyed by different firms. However, another potential problem is the possibility of a reverse relationship between financing sources and technology investment/exporting. As discussed previously, we introduce the financial variables lagged one period to alleviate this potential problem. Nevertheless, as a robustness check, we also instrument the financing variables with their higher lagged values.

\section{Data}

\subsection{Data Source}

In order to evaluate the role of different financing sources for exporting and technology investments, we draw on a firm-level panel data from the Indian service sector. The dataset comes from the Prowess database maintained by the Centre for Monitoring the Indian Economy (CMIE). ${ }^{15}$ The firms in this dataset are representative of services sector in India and cover all service industries. However, for the purpose of this analysis we exclude banking and non-banking financial institutions, as well as wholesale and retail traders given that the unique nature of their core business is beyond the purpose of this paper. ${ }^{16}$ We also exclude observations in the $0.1 \%$ tails for each of the continuous

\footnotetext{
${ }^{14}$ Previous studies have also shown the importance of the firm's productivity for exporting and technological investments. While, data constrains prevent us from calculating a measure of total factor productivity (TFP) for the full sample of firms, we calculated this measure for the sample of firms with full information on inputs and outputs using the Levinsohn and Petrin (2003) technique, and found the coefficient on our productivity measure to be insignificant. More importantly, the effects of our financial and control variables remain robust to the inclusion of firm's productivity on this subsample of firms.

15 The Prowess database contains detailed financial statements information of listed companies, unlisted public companies and private companies of all sizes and ownership groups belonging to manufacturing, services, and other utilities. The firms covered by this database account for $70 \%$ of the industrial output, $75 \%$ of corporate taxes and more than $95 \%$ of excise taxes collected by the government (CMIE).

${ }^{16}$ Banking and non-banking financial institutions account for $22.57 \%$ of the service firms included in Prowess during our study period. We exclude these institutions from our empirical analysis as their very nature is to provide finance to firms and other economic agents. Similarly, wholesale and retail traders (which represent $23.3 \%$ of the number of service firms in Prowess) were excluded from our analysis as their core business is the distribution of goods and merchandises.
} 
Table 1 Definition of variables

\begin{tabular}{ll}
\hline Variable & Definition \\
\hline Tech & Dummy indicating a firm investing in technology \\
Export & Dummy indicating a firm exporting services \\
Internal funding & Logarithm of retained profits \\
External financing through banks & Logarithm of borrowings from banks and \\
& financial institutions \\
External financing through equity markets & Logarithm of equity capital \\
Other finance & Logarithm of other sources of finance including \\
& loans from promoters, intercorporate loans, \\
& foreign currency borrowing, and trade credits \\
amongst others. & Firm's age since incorporation year. \\
Age & $\begin{array}{l}\text { Total assets divided by the mean assets of firms } \\
\text { in the corresponding industry }\end{array}$ \\
Size & $\begin{array}{l}\text { Dummy variables for each of the following ownership } \\
\text { statues: private firms without group affiliations; } \\
\text { foreign firms; private firms with group affiliations; } \\
\text { and state-owned firms. In our empirical analysis } \\
\text { Imports of capital goods }\end{array}$ \\
& $\begin{array}{l}\text { Logarithm of imports of services } \\
\text { Logarithm of imports of capital goods }\end{array}$ \\
&
\end{tabular}

variables in the empirical regressions to control for outliers, which left us with an unbalanced panel dataset of 5148 service firms over the period 1999-2010. ${ }^{17}$

\subsection{Descriptive Analysis}

Table 2 reports a range of summary statistics of the key variables used in our empirical analysis according to firms' exporting and technological statuses. Several points stand out. Approximately $41 \%$ of firms exported or invested in technology at some point during the period of analysis, and $12 \%$ of them were engaged in both activities. However, overall there was an important fraction of service firms that invested in technology without exporting (17\%), or that exported without investing in technology $(12 \%)$. Firms that both exported and invested in technology displayed significantly higher access to internal and external financing sources. These firms were also larger and more engaged in international markets through importing.

It is also worth noting that firms' engagement in technology investments and exporting varies widely across service industries. As Fig. 1 shows, technology intensive industries such as telecommunication services, naturally displayed a relatively higher proportion of

\footnotetext{
${ }^{17}$ As mentioned in the introduction of this paper, we are interested in evaluating the role of different financial sources available to Indian service firms following the liberalization reforms implemented in the 1990s, which included the liberalization of the financial market and the opening up of the economy. Thus, we focus on the first decade of the increasingly liberalized post-reform period, when India witnessed a surge in exports and technology investments, in parallel with a greater availability of finance for firms, including the expansion of bank lending and equity finance.
} 
firms investing in technology, compared to less technologically intensive industries, such as business consultancy. Despite these differences, Fig. 1 reveals that, except for the telecommunications service industry, the fraction of service firms conducting technology investments dramatically increased during the period of analysis.

As with technology investments, the incidence of firms selling in foreign markets through exports also displayed a high degree of variability across industries, as shown in Fig. 2. These differences are likely to reflect the nature of the industry (e.g. differences in mode of delivery) as well as international trade regulations (e.g. differences in barriers to exporting).

\section{Empirical Results}

We now turn to empirically analysing the role of financing sources on firms' decision to invest in technology and export, allowing for the possibility that these two activities are jointly determined, rather than the result of independent processes. More precisely, we compare the effects of internal sources and two types of external financing sources, namely borrowings from banks and financial institutions, equity capital, and other financing sources, such as loans from promoters, intercorporate loans, foreign currency borrowing, and trade credits amongst others. A series of complementary robustness checks are undertaken.

Before we start our estimations it is important to check that our financing sources variables are not highly correlated, as this might cause multi-collinearity problems in our estimations. To this end, in Table 6 in the appendix we present the correlation

Table 2 Firms' characteristics by exporting and technology investment status

\begin{tabular}{llllll}
\hline Variable & $\begin{array}{l}\text { No Tech No } \\
\text { Exporting }\end{array}$ & $\begin{array}{l}\text { Only } \\
\text { Tech }\end{array}$ & $\begin{array}{l}\text { Only } \\
\text { Exporting }\end{array}$ & $\begin{array}{l}\text { Both Tech } \\
\text { and Exporting }\end{array}$ & All firms \\
\hline Internal funding & 0.656 & 1.349 & 1.762 & 2.272 & 1.095 \\
External financing through banks & 1.075 & 2.173 & 1.944 & 2.498 & 1.534 \\
External financing through equity markets & 2.202 & 3.074 & 3.272 & 3.696 & 2.653 \\
Other finance & 1.857 & 3.12 & 3.087 & 3.701 & 2.435 \\
Age & 20.3 & 15.69 & 16.23 & 16.82 & 18.62 \\
Size & 0.347 & 1.107 & 0.977 & 1.855 & 0.729 \\
Imported services & 0.083 & 0.318 & 1.47 & 1.797 & 0.487 \\
Imported capital goods & 0.0728 & 0.341 & 0.747 & 1.117 & 0.321 \\
Private firms without group affiliations & 0.707 & 0.61 & 0.52 & 0.50 & 0.64 \\
Foreign firms & 0.02 & 0.02 & 0.08 & 0.06 & 0.03 \\
Private with group affiliations & 0.24 & 0.29 & 0.39 & 0.41 & 0.29 \\
State-owned firms & 0.04 & 0.08 & 0.03 & 0.02 & 0.04 \\
N ${ }^{\circ}$ of observations & 14,905 & 4348 & 2936 & 2956 & 25,145 \\
\% & $59 \%$ & $17 \%$ & $12 \%$ & $12 \%$ & $100 \%$ \\
\hline
\end{tabular}

Notes: The table compares the mean of the main variables among firms in different groups. The dataset is a sample of Indian service firms during the period of 1999-2010. "No Tech No Exporting" refers to firms that neither invest in technology nor export; "Only Tech" refers to firms investing in technology but not exporting; "Only Exporting" refers to firms that export but did not invest in technology; "Both Tech and Exporting" means firms both export and invest in technology. "All firms" shows the mean values of all firms. The continuous variables are in natural logarithm except age and size. All the money values are in Millions of Rupees 


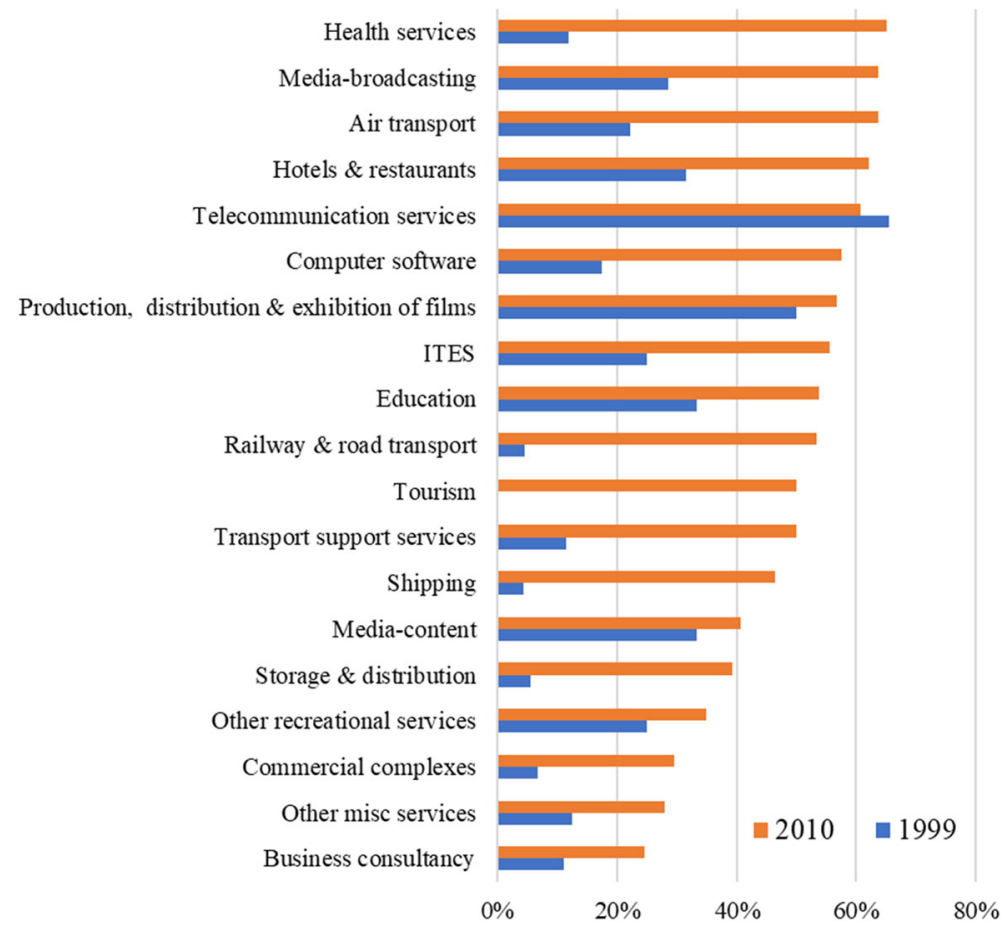

Notes: The figure shows the proportion of firms that conduct technology investment for the year of 1999 and 2010 by industry for a sample of Indian services firms. Data Source: The Prowess database and authors' calculations using the dataset

Fig. 1 Proportion of service firms investing in technology by industry

matrix of our main explanatory variables. The results from this correlation matrix reassure us that our financial indicators (as well as other explanatory variables) do not display high levels of association, suggesting that multi-collinearity is unlikely to be an issue in our estimations. We do, however, do some further investigation of this issue later by considering whether our findings are sensitive to variation in the specification.

\subsection{Baseline Results}

Table 3 contains parameter estimates of the model depicted by eqs. (3a) and (3b) in section 2. Single equation estimates using univariate Probit estimators are presented in columns (1) and (2), and the corresponding estimates from the simultaneous equation estimation using the bivariate Probit estimator described in section 2 are shown in columns (3) and (4). In line with previous theoretical and empirical literature (Roberts and Tybout, 1997; Das, Roberts and Tybout, 2007; Aw et al., 2011), our results in Table 3 show that there is a high level of persistence in firms' decisions to invest in technology and export, as judged by the positive estimated coefficients of the lag values of the dependent variables. Also, consistent with the parallel literature in the manufacturing sector (Aw et al., 2007; Máñez et al., 2014), there is a robust and positive mutual relationship between firms' exporting and technology investments decisions in the service sector (i.e. firms that export are more likely to invest in 


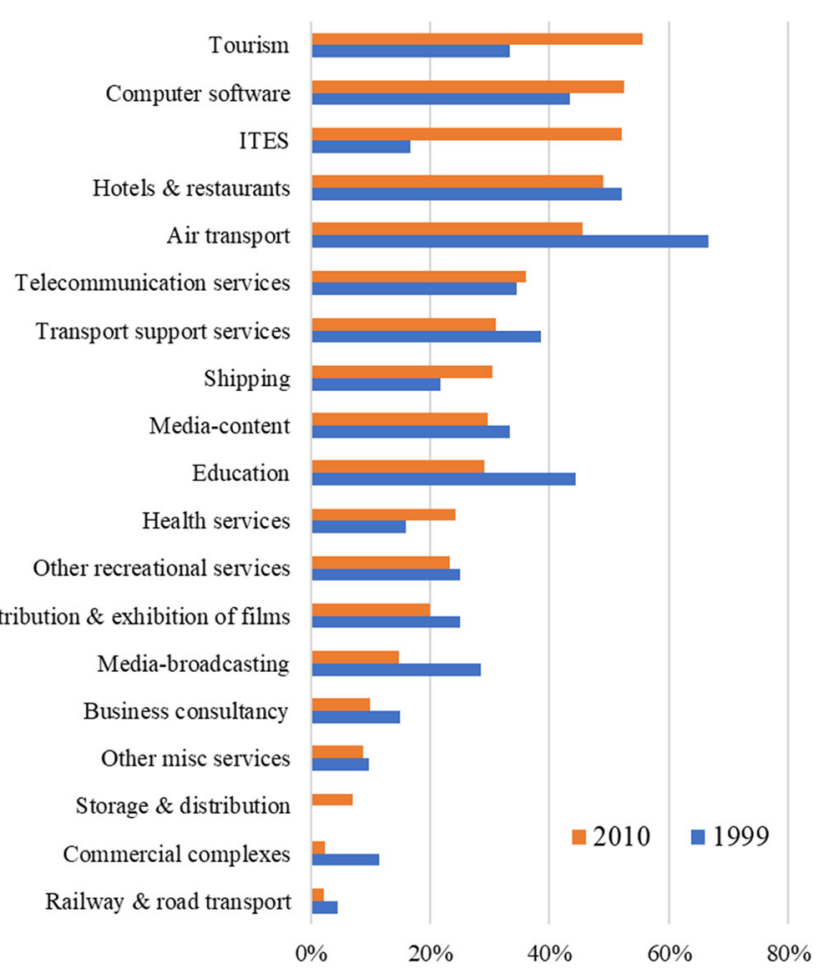

Notes: The figure shows the proportion of exporters for the year of 1999 and 2010 by industry for a sample of Indian services firms. Data Source: The Prowess database and authors' calculations using the dataset

Fig. 2 Proportion of service firms exporting by industry

technology, and vice versa). Moreover, similar with a recent literature on firms' exporting and importing behaviour for manufacturing firms (Bas, 2012; Feng et al., 2016; Gullstrand et al., 2016), our results reveal a positive relationship between exporting and the imports of services and capital goods. However, firms' international engagement through importing does not appear to affect their technological decisions. Finally, our results indicate that younger service firms are more dynamic in reaching export markets and engaging in technology investments; whereas their size is irrelevant for these decisions. This is consistent with Zahler et al. (2014) which find that services exporters are not necessarily much larger than non-exporters. ${ }^{18}$

\footnotetext{
${ }^{18}$ As mentioned in section 2, although previous studies have highlighted the importance of firm's productivity for exporting and technological investments, missing values of key input variables (such as intermediate inputs) amongst some service firms prevent us from calculating a measure of total factor productivity (TFP) for our full sample of firms. To check that our results are not affected by the exclusion of firms' productivity, we calculated TFP for the sample of firms with full information on inputs and estimate the regressions on this subsample of firms including our productivity measure. The results from these estimations, reported in appendix Table 7, show that the coefficient on TFP is positive but insignificant. More importantly, the effects of our financial and control variables remain robust to the inclusion of firm's productivity on this subsample of firms.
} 
Table 3 also confirms that, as discussed in Section 2, the simultaneous estimation does not affect the consistency of the individual Probit estimates, as judged by the similar estimated coefficients across the two sets of estimations. Thus, a main advantage of using a bivariate Probit estimator to estimate our model simultaneously, is that it provides us with an accurate correlation between our two binary dependent variables without any lost in consistency. As mentioned in Section 2, the correlation between exporting and investing in technology is captured by the conditional tetrachoric correlation of the error terms, $\rho$. The test of the null hypothesis of zero correlation of the disturbance terms of eqs. (3a) and (3b) is strongly rejected $(\rho=0.21)$, providing strong support for a link between exporting and technology investments amongst Indian services firms. Thus, in line with previous findings for the manufacturing sector, our results also suggest the existence of potential complementarities between exporting and investing in technology in the service sector, whereby the marginal return of investing in technology is likely to increase with exporting, and vice versa. Thus, from a firm's manager perspective, it is potentially more optimal to engage in exporting and investing in technology rather than investing exclusively in only one of these activities. From a policy perspective, it would be important to identify what drives these potential complementarities to better support firms in the service sector. Although the main focus of this paper is not to test the existence of such complementarities per se, we provide insights on the joint occurrence of exporting and investing in technology in the service sector, and on the role of different financial sources to support these decisions.

Having found support for the hypothesis of interdependence of firms' technological efforts and export market participation amongst Indian service firms, we proceed to provide the marginal effects of various sources of finance available to firms to support their exporting and technological investments, allowing these decisions to be jointly determined (i.e. using bivariate Probit estimator). These marginal effects, reported in Table 4, are obtained from estimating our dynamic model (eqs. 3a and 3b), with and without controlling for potential firm's unobserved heterogeneity as described in Section $2 .{ }^{19}$ Overall, our results remain robust to the inclusion of the initial values of the explanatory variables as a way to control for unobserved heterogeneity. ${ }^{20}$

Finally, although we reported earlier that the correlations between the alternative sources of finance were not such as to give obvious concern about collinearity issues, we do report in Table 11 on the systematic removal of each source of finance in turn

\footnotetext{
${ }^{19}$ The marginal effects of all control variables are reported in Table 8 in the Appendix.

${ }^{20}$ A potential econometric concern in estimating equations (3a) and (3b) is the possibility that a firm's exporting and/or technological investments might affect its ability to access diverse sources of finance. Thus, as a further guard against this potential endogeneity arising from reverse causality, we instrument our financial variables using their three-period lagged values $\left(F I N_{i t-3}\right)$ and employ Roodman (2011) approach to estimate a system of six equations that besides the technology investment and export ones, four equations in which internal funding, external financing through banks, external financing through markets, other finance are regressed on their respective instruments and control variables. These results are reported in Table 9 in the appendix. The coefficients of the financing sources are consistent with our main results, and the tests on the correlations of errors between regression equations for financing sources and the export and technology investment equations indicate that our estimations in Table 4 do not suffer from endogeneity problems. As a further robustness check we estimate a dynamic bivariate linear probability model, which despite its wellknown disadvantages (i.e. the possibility of generating probability predictions outside the $0-1$ range; and heteroscedastic in the error terms), allows better interpretation of the coefficients. We estimate the model using SURs estimation procedure proposed by Zellner $(1962,1963)$ and Zellner and Huang (1962). These results, presented in Table 10 in the appendix, are in line with our main results in Table 4.
} 
Table 3. Exporting and investing in technology: Parameter estimates from univariate and bivariate probit estimations.

\begin{tabular}{|c|c|c|c|c|}
\hline \multirow[t]{3}{*}{ Variables } & \multicolumn{2}{|c|}{ Univariate Probit } & \multicolumn{2}{|c|}{ Bivariate Probit } \\
\hline & (1) & (2) & (3) & (4) \\
\hline & Tech & Export & Tech & Export \\
\hline \multirow[t]{2}{*}{ internal funding $\mathrm{t}_{\mathrm{t}-1}$} & $0.0676^{* * *}$ & $0.0836^{* * *}$ & $0.0678 * * *$ & $0.0830 * * *$ \\
\hline & $(0.010)$ & $(0.015)$ & $(0.010)$ & $(0.015)$ \\
\hline \multirow[t]{2}{*}{ external financing through banks $\mathrm{s}_{\mathrm{t}-1}$} & $0.0426^{* * *}$ & -0.0023 & $0.0427 * * *$ & -0.0001 \\
\hline & $(0.009)$ & $(0.013)$ & $(0.009)$ & $(0.013)$ \\
\hline \multirow[t]{2}{*}{ external financing through equity markets $\mathrm{t}_{\mathrm{t}-1}$} & $0.0325 *$ & 0.0231 & $0.0330 *$ & 0.0231 \\
\hline & $(0.018)$ & $(0.024)$ & $(0.017)$ & $(0.024)$ \\
\hline \multirow[t]{2}{*}{ other finance $_{\mathrm{t}-1}$} & $0.0774 * * *$ & $0.0326^{* *}$ & $0.0776^{* * * *}$ & $0.0332 * *$ \\
\hline & $(0.012)$ & $(0.016)$ & $(0.012)$ & $(0.016)$ \\
\hline \multirow[t]{2}{*}{$\operatorname{Tech}_{\mathrm{t}-1}$} & $1.2827 * * *$ & $0.1658 * * *$ & $1.2825 * * *$ & $0.1791 * * *$ \\
\hline & $(0.033)$ & $(0.038)$ & $(0.033)$ & $(0.038)$ \\
\hline \multirow[t]{2}{*}{ Export $_{\mathrm{t}-1}$} & $0.2294 * * *$ & $2.6087 * * *$ & $0.2306^{* * *}$ & $2.6078 * * *$ \\
\hline & $(0.034)$ & $(0.046)$ & $(0.034)$ & $(0.046)$ \\
\hline \multirow[t]{2}{*}{ age $_{t-1}$} & $-0.0074 * * *$ & $-0.0030^{* *}$ & $-0.0075^{* * *}$ & $-0.0031^{* * *}$ \\
\hline & $(0.001)$ & $(0.001)$ & $(0.001)$ & $(0.001)$ \\
\hline \multirow[t]{2}{*}{$\operatorname{size}_{\mathrm{t}-1}$} & 0.0143 & -0.0155 & 0.0141 & -0.0158 \\
\hline & $(0.009)$ & $(0.014)$ & $(0.009)$ & $(0.013)$ \\
\hline \multirow[t]{2}{*}{ imported services $_{\mathrm{t}-1}$} & -0.0103 & $0.0992 * * *$ & -0.0101 & $0.0962 * * *$ \\
\hline & $(0.017)$ & $(0.028)$ & $(0.017)$ & $(0.028)$ \\
\hline \multirow[t]{2}{*}{ imported capital goods t-1 $_{\text {im }}$} & -0.0079 & $0.0414 *$ & -0.0088 & $0.0399 *$ \\
\hline & $(0.019)$ & $(0.023)$ & $(0.019)$ & $(0.023)$ \\
\hline \multirow[t]{2}{*}{ constant } & $-0.7027 * * *$ & $-2.3238 * * *$ & $-0.7020 * * *$ & $-2.3443 * * *$ \\
\hline & $(0.166)$ & $(0.212)$ & $(0.166)$ & $(0.211)$ \\
\hline initial values & yes & yes & yes & yes \\
\hline ownership dummies & yes & yes & yes & yes \\
\hline year dummies & yes & yes & yes & yes \\
\hline \multirow[t]{5}{*}{ industry dummies } & yes & yes & yes & yes \\
\hline & & & $\rho=0.2056^{* *}$ & \\
\hline & & & $(0.0234)$ & \\
\hline & N obs: 18,70 & & $\mathrm{~N}$ obs: 18,70 & \\
\hline & N firms: 443 & & $\mathrm{~N}$ firms: 443 & \\
\hline
\end{tabular}

Note: $* p<0.10, * * p<0.05, * * * p<0.01$. The regressions are estimated on our service firms sample for the period 1999-2010. Robust firm-clustered standard errors in parentheses. "Tech" and "Export" are two dummies that indicate firms invest in technology and export services respectively. The continuous variables are in natural logarithm except age and size. The "initial values" include the initial value of internal funding, external financing through banks, external financing through equity markets, other finance, size, imported services and imported capital goods

from the specification. In this way we can limit any omitted variable bias, but check on any sensitivity on coefficient sign and significance to these marginal changes in 
specification. Reassuringly we find that there is no change in the findings in Table 11 from those in our base results in Table 4. It is interesting also to find that the magnitude of the estimated coefficients is generally absolutely larger in Table 11 (with omitted variables) than Table 4 (the full specification). This points to the possible bias associated with work that investigates the impact of only some sources of finance on the technology investment and exporting decision of firms. A contribution of the present work is that it avoids this potential bias by investigating the impact of all finance sources on these decisions of firms.

The main results from Table 4 can be summarized as follows:

1. Internally generated financial funds through retained profits are essential for Indian service firms to fund their technological efforts and international expansion. Our results show that keeping everything else constant, a $10 \%$ increase in firms' retained profits raises the probability of exporting and investing in technology by 8 and 17 percentage points on average, respectively.

2. Indian service firms also rely on lending from the banking system and from "other" sources of finance (including loans from promoters, intercorporate loans, foreign currency borrowing, and trade credits, amongst others) to fund their technological opportunities. Thus, a $10 \%$ increase in access to any of these sources of finance enhances the probability that a firm invest in technology by 10 and 19 percentage points on average, respectively.

3. In contrast to the positive effect of bank lending on firm's technology investments, this type of finance does not appear to be an important source of funding for exporting activities amongst Indian service firms. This is consistent with the findings of Lancheros and Demirel (2012), which demonstrated that long-and short-term bank borrowing are insignificant for Indian service firms' exporting decisions. Similarly, despite the positive and relatively large impact of "other" sources of finance on firms' technological efforts, these financing sources only have a modest and less significant impact in supporting service firms to expand their international operations via exporting.

4. Finally, our estimations show that funds raised from equity markets have not contributed to the exporting and technological efforts of Indian service firms. Overall, our results are in line with Allen et al. (2012) who find that financial markets have played a limited role in financing the growth of Indian firms. Instead, firms in India fund their technological and exporting investments mainly with their own funds or resorting to other financial mechanism outside the financial market. ${ }^{21}$

\subsection{Further Analysis: Does the Type of Service Matter?}

Despite evidence from previous works about the limited role of the equity market to support firms' growth in India, to some extent we still find striking that equity finance does not appear to be a highly significant source of finance to fund service firms'

\footnotetext{
${ }^{21}$ An important implication of our analysis is that failing to control for all sources of finance available to firms, as has been standard in the previous finance-investment literature, may introduce bias in the estimations of the parameters of interest.
} 
Table 4. Role of financing sources on exporting and investing in technology. Marginal effects from dynamic bivariate probit estimations.

\begin{tabular}{|c|c|c|c|c|}
\hline \multirow[t]{2}{*}{ Variables } & (1) & $(2)$ & (3) & (4) \\
\hline & Tech & Export & Tech & Export \\
\hline \multirow[t]{2}{*}{ internal funding $\mathrm{t}_{\mathrm{t}-1}$} & $0.0227 * * *$ & $0.0096 * * *$ & $0.0167 * * *$ & $0.0080 * * *$ \\
\hline & $(0.002)$ & $(0.001)$ & $(0.003)$ & $(0.001)$ \\
\hline \multirow[t]{2}{*}{ external financing through banks $\mathrm{t}_{\mathrm{t}-1}$} & $0.0075 * * *$ & 0.0000 & $0.0105 * * *$ & -0.0000 \\
\hline & $(0.002)$ & $(0.001)$ & $(0.002)$ & $(0.001)$ \\
\hline \multirow[t]{2}{*}{ external financing through equity markets $\mathrm{t}_{\mathrm{t}-1}$} & -0.0009 & -0.0001 & $0.0081^{*}$ & 0.0022 \\
\hline & $(0.002)$ & $(0.001)$ & $(0.004)$ & $(0.002)$ \\
\hline \multirow[t]{2}{*}{ other finance $\mathrm{t}_{-1}$} & $0.0159 * * *$ & $0.0020^{*}$ & $0.0191 * * *$ & $0.0032 * *$ \\
\hline & $(0.002)$ & $(0.001)$ & $(0.003)$ & $(0.002)$ \\
\hline Past values of the dependent variables & yes & yes & yes & yes \\
\hline Full set of control variables & yes & yes & yes & yes \\
\hline initial values & - & - & yes & yes \\
\hline ownership dummies & yes & yes & yes & yes \\
\hline year dummies & yes & yes & yes & yes \\
\hline \multirow[t]{5}{*}{ industry dummies } & yes & yes & yes & yes \\
\hline & \multicolumn{2}{|c|}{$\rho=0.2084 * * *$} & \multicolumn{2}{|c|}{$\rho=0.2056^{* * *}$} \\
\hline & \multicolumn{2}{|l|}{$(0.0232)$} & \multicolumn{2}{|l|}{$(0.0234)$} \\
\hline & \multicolumn{2}{|c|}{ N obs: 18,705} & \multicolumn{2}{|c|}{$\mathrm{N}$ obs: 18,705} \\
\hline & \multicolumn{2}{|c|}{ N firms: 4434} & \multicolumn{2}{|c|}{ N firms: 4434} \\
\hline
\end{tabular}

Note: $* p<0.10, * * p<0.05$, *** $p<0.01$. The regressions are estimated on our service firms sample for the period 1999-2010. Robust firm-clustered standard errors in parentheses. The control variables include age, size, imported services and imported capital goods. The "initial values" include the initial value of internal funding, external financing through banks, external financing through equity markets, other finance, size, imported services and imported capital goods

technological investments, as this type of finance is commonly regarded as a wellsuited form of funding to support innovative activities amongst manufacturing firms. A potential reason behind our results presented in Table 4 is the high level of heterogeneity that characterizes the service sector, and the consequent possibility that different types of funding might play a differential role across industries in the sector. To test this conjecture, we distinguish between modern and traditional service industries. Compared to traditional services, modern services rely more on information and knowledge technologies to produce high value-added services. Therefore, their technological investments might be more closely related with the technological efforts of manufacturing firms. To gauge a better understanding of the role of various financing sources across service industries, we interact our financing variables with a dummy variable indicating whether a firm operates in a modern $(=1)$ or a traditional $(=0)$ industry. ${ }^{22}$

\footnotetext{
${ }^{22}$ Following Eichengreen and Gupta (2013), we treat industries of business consultancy, commercial complexes, computer software, ITES and telecommunication services as modern services and the rest as traditional services. According to this classification, in our sample $50.19 \% \%$ of firms are classified as modern while the remaining $49.81 \%$ are categorized in the traditional service sector.
} 
The results from these estimations are reported in Table 5 and indicate that the role of different financing sources varies across the two groups of industries in the service sector. ${ }^{23}$ While the magnitude and significance of the marginal effects associated to our financial sources variables remains largely unchanged for service firms operating in the traditional sector; our exercise uncovers a relatively important positive role of new equity raised through equity markets to support modern service firms' exporting and technological efforts (as judged by the positive and significant marginal effect of our equity finance variable interacted with our modern sector indicator). Moreover, our exercise shows that more indebted modern service firms are less likely to export. This results is consistent with Hogan and Hutson (2005)'s paper which investigates the capital structure of new technology-based firms in Ireland and concludes that the most important source of external finance for these firms is equity financing, rather than banking lending.

Overall, our results suggest that various financing sources play a heterogeneous role in supporting different types of firms' investment decisions (i.e. exporting and technological investments in our case) and that their role varies across industries (i.e. modern and traditional service industries in this paper). These results point to the need for considering the wide range of financial alternatives available to firms when evaluating the role of finance for firm's investment behaviour, as well as considering the characteristics of the industries in which firms operate. This type of analysis is vital for a better design of public policies aimed to support firm's investment decisions through finance. To our knowledge no previous studies have mapped the source of finance to different types of firms' investment decisions.

\section{Conclusions}

The technology investments and exporting decisions of services firms remain underexplored in the literature, despite their prominent role for economic growth and prosperity. In particular, we know very little about the importance of financial factors in stimulating these activities. This study investigates for the first time the role of different types of funding to support service firms' decisions to invest in technology and export, allowing for the possibility that these decisions are jointly determined.

The results from this study indicate that the role of financial markets in stimulating technological investments and exporting activities of Indian service firms was limited over our study period. Instead, these firms rely more intensively on their own internal funds and other sources of finance to sustain these investments. Our results are in line with some related studies examining the role of financial sources for firms' growth in the Indian manufacturing sector (i.e. Allen et al., 2012). However, our results also show that the importance of different financial sources crucially depends on the type of industry under consideration. For firms operating in modern service industries, characterised by the continuous introduction of new technologies, funding from equity markets constitutes a vital source of finance to support their technological efforts.

\footnotetext{
${ }^{23}$ The marginal effects presented in Table 5 are obtained from estimating our dynamic model described in Section 2, controlling for the full set of control of explanatory variables and accounting for potential unobserved firm heterogeneity. Results of the marginal effects for all variables are available upon request.
} 
Table 5. Role of financing sources on exporting and investing in technology: a comparison of traditional and modern services. Marginal effects from dynamic bivariate probit estimations.

\begin{tabular}{|c|c|c|}
\hline \multirow[t]{2}{*}{ Variables } & (1) & \\
\hline & Tech & Export \\
\hline \multirow[t]{2}{*}{ internal funding $\mathrm{t}_{\mathrm{t}-1}$} & $0.0171 * * *$ & $0.0079 * * *$ \\
\hline & $(0.003)$ & $(0.002)$ \\
\hline \multirow[t]{2}{*}{ external financing through banks $\mathrm{t}_{\mathrm{t}-1}$} & $0.0135^{* * *}$ & 0.0022 \\
\hline & $(0.003)$ & $(0.002)$ \\
\hline \multirow[t]{2}{*}{ external financing through equity markets $\mathrm{t}_{\mathrm{t}-1}$} & 0.0034 & -0.0005 \\
\hline & $(0.005)$ & $(0.003)$ \\
\hline \multirow[t]{2}{*}{ other finance $_{t-1}$} & $0.0197 * * *$ & $0.0053^{* * *}$ \\
\hline & $(0.004)$ & $(0.002)$ \\
\hline \multirow[t]{2}{*}{ internal sources $_{\mathrm{t}-1} *$ modern } & -0.0008 & 0.0008 \\
\hline & $(0.004)$ & $(0.002)$ \\
\hline \multirow[t]{2}{*}{ external financing through banks $\mathrm{t}-1 *$ modern } & -0.0059 & $-0.0050 * *$ \\
\hline & $(0.004)$ & $(0.002)$ \\
\hline \multirow[t]{2}{*}{ external financing through equity markets $\mathrm{t}-1^{*}$ modern } & $0.0099 * *$ & $0.0060^{* *}$ \\
\hline & $(0.005)$ & $(0.002)$ \\
\hline \multirow[t]{2}{*}{ other finance $_{\mathrm{t}-1} *$ modern } & -0.0007 & $-0.0039 *$ \\
\hline & $(0.004)$ & $(0.002)$ \\
\hline \multirow[t]{2}{*}{ modern } & 0.0485 & 0.0202 \\
\hline & $(0.043)$ & $(0.022)$ \\
\hline Past values of the dependent variables & yes & yes \\
\hline Full set of control variables & yes & yes \\
\hline initial values & yes & yes \\
\hline ownership dummies & yes & yes \\
\hline year dummies & yes & yes \\
\hline \multirow[t]{5}{*}{ industry dummies } & yes & yes \\
\hline & $\rho=0.2042 * * *$ & \\
\hline & $(0.0234)$ & \\
\hline & $\mathrm{N}$ obs: 18,705 & \\
\hline & N firms: 4434 & \\
\hline
\end{tabular}

Note: $* \mathrm{p}<0.10, * * \mathrm{p}<0.05, * * * \mathrm{p}<0.01$. The regressions are estimated on our service firms sample for the period 1999-2010. Average marginal effects are presented in the table. Robust firm-clustered standard errors in parentheses. The control variables include age, size, imported services and imported capital goods. The "Initial values" include the initial value of internal funding, external financing through banks, external financing through equity markets, other finance, size, imported services and imported capital goods

Our study is a first step towards a better understanding of the role of diverse forms of finance for firms' strategic decisions in the service sector. In the process it seeks to avoid the bias that may result from concentrating only on specific sources of finance. From a public policy perspective, a clear understanding of the importance of different types of funding to support firms' investment opportunities is crucial to better tailor 
programs and reforms according to specific policy objectives, such as promoting exports and/or technological investments. Overall, our research suggests that looking at the heterogeneous effects of different funding sources alongside the characteristics of the industries in which firms operate, is an urgent matter, as it sheds much needed light on the mechanism through which finance affects firm's performance.

A possible omission of our study is that we focus only on the effects of financing sources on firms' decisions to invest in technology and exporting and do not take into account the importing decision, which may also important for firm performance. This opens prospects of future research which may consider how different financing sources affect technology investment, exporting and importing decisions of services firms, and how in turn this affects the performance of services firms.

Acknowledgements We would like to thank the editor and two anonymous referees for their very thoughtful comments and suggestions. Any errors that remain are the authors' responsibility. Shubin Yang acknowledges that this research was supported by the Fundamental Research Funds for the Central Universities (CCNU19A03016; CCNU17XJ021).

\section{Appendix}

Table 6 Correlation matrix

\begin{tabular}{|c|c|c|c|c|c|c|c|c|}
\hline & $\begin{array}{l}\text { internal } \\
\text { funding }\end{array}$ & $\begin{array}{l}\text { external } \\
\text { financing } \\
\text { through } \\
\text { banks }\end{array}$ & $\begin{array}{l}\text { external } \\
\text { financing } \\
\text { through } \\
\text { equity } \\
\text { markets }\end{array}$ & $\begin{array}{l}\text { other } \\
\text { finance }\end{array}$ & age & size & $\begin{array}{l}\text { imported } \\
\text { services }\end{array}$ & $\begin{array}{l}\text { imported } \\
\text { capital } \\
\text { goods }\end{array}$ \\
\hline internal funding & 1 & & & & & & & \\
\hline $\begin{array}{l}\text { external financing } \\
\text { through banks }\end{array}$ & 0.345 & 1 & & & & & & \\
\hline $\begin{array}{l}\text { external financing } \\
\text { through equity } \\
\text { markets }\end{array}$ & 0.371 & 0.528 & 1 & & & & & \\
\hline other finance & 0.445 & 0.578 & 0.547 & 1 & & & & \\
\hline Age & 0.0133 & -0.0411 & -0.13 & -0.0417 & 1 & & & \\
\hline Size & 0.356 & 0.296 & 0.311 & 0.386 & 0.0329 & 1 & & \\
\hline imported services & 0.435 & 0.276 & 0.354 & 0.406 & -0.055 & 0.297 & 1 & \\
\hline $\begin{array}{l}\text { imported capital } \\
\text { goods }\end{array}$ & 0.381 & 0.343 & 0.373 & 0.421 & -0.0515 & 0.27 & 0.534 & 1 \\
\hline
\end{tabular}

Note: The table shows the correlation between the main variables of service firms in our sample during 19992010 
Table 7. Exporting and investing in technology: Parameter estimates from a subsample including TFP.

\begin{tabular}{|c|c|c|c|c|}
\hline \multirow[t]{2}{*}{ Variables } & (1) & (2) & (3) & (4) \\
\hline & Tech & Export & Tech & Export \\
\hline \multirow[t]{2}{*}{ internal funding $\mathrm{t}_{\mathrm{t}-1}$} & $0.0694 * * *$ & $0.0824 * * *$ & $0.0476 * * *$ & $0.0707 * * *$ \\
\hline & $(0.010)$ & $(0.014)$ & $(0.011)$ & $(0.017)$ \\
\hline \multirow[t]{2}{*}{ external financing through banks $\mathrm{t}_{\mathrm{t}-1}$} & $0.0178 * *$ & -0.0147 & $0.0299 * * *$ & -0.0160 \\
\hline & $(0.008)$ & $(0.011)$ & $(0.010)$ & $(0.013)$ \\
\hline \multirow[t]{2}{*}{ external financing through equity markets $\mathrm{t}_{\mathrm{t}-1}$} & -0.0179 & -0.0043 & 0.0173 & 0.0146 \\
\hline & $(0.011)$ & $(0.014)$ & $(0.019)$ & $(0.027)$ \\
\hline \multirow[t]{2}{*}{ other finance $_{t-1}$} & $0.0408 * * *$ & 0.0196 & $0.0544 * * *$ & 0.0293 \\
\hline & $(0.011)$ & $(0.014)$ & $(0.014)$ & $(0.019)$ \\
\hline \multirow[t]{2}{*}{$\operatorname{Tech}_{\mathrm{t}-1}$} & $1.1973 * * *$ & $0.1257 * * *$ & $1.1882 * * *$ & $0.1193^{* * *}$ \\
\hline & $(0.037)$ & $(0.041)$ & $(0.037)$ & $(0.042)$ \\
\hline \multirow[t]{2}{*}{ Export $_{t-1}$} & $0.1338 * * *$ & $2.5712^{* * * *}$ & $0.1206^{* * *}$ & $2.5626^{* * * *}$ \\
\hline & $(0.036)$ & $(0.050)$ & $(0.036)$ & $(0.050)$ \\
\hline \multirow[t]{2}{*}{ age $_{t-1}$} & $-0.0075 * * *$ & -0.002 & $-0.0071 * * *$ & -0.0017 \\
\hline & $(0.001)$ & $(0.001)$ & $(0.001)$ & $(0.001)$ \\
\hline \multirow[t]{2}{*}{$\operatorname{size}_{\mathrm{t}-1}$} & 0.0111 & $-0.0220^{*}$ & $0.0232 * *$ & -0.0126 \\
\hline & $(0.008)$ & $(0.012)$ & $(0.011)$ & $(0.015)$ \\
\hline \multirow[t]{2}{*}{ imported services $_{\mathrm{t}-1}$} & 0.0002 & $0.1437 * * *$ & -0.0078 & $0.1149^{* * *}$ \\
\hline & $(0.015)$ & $(0.024)$ & $(0.019)$ & $(0.030)$ \\
\hline \multirow[t]{2}{*}{ imported capital goods $\mathrm{gt}_{\mathrm{t}-1}$} & 0.0162 & $0.0726^{* * * *}$ & 0.0030 & $0.0449 *$ \\
\hline & $(0.015)$ & $(0.020)$ & $(0.019)$ & $(0.024)$ \\
\hline \multirow[t]{2}{*}{$\operatorname{lnTFP}{ }_{t-1}$} & 0.0121 & 0.0147 & 0.0089 & 0.0223 \\
\hline & $(0.011)$ & $(0.015)$ & $(0.015)$ & $(0.022)$ \\
\hline \multirow[t]{2}{*}{ constant } & $-0.3305^{*}$ & $-2.3778 * * *$ & $-0.3420^{*}$ & $-2.4243 * * *$ \\
\hline & $(0.175)$ & $(0.184)$ & $(0.180)$ & $(0.192)$ \\
\hline initial values & & & yes & yes \\
\hline ownership dummies & yes & yes & yes & yes \\
\hline year dummies & yes & yes & yes & yes \\
\hline \multirow[t]{5}{*}{ industry dummies } & yes & yes & yes & yes \\
\hline & $\rho=0.1435^{* * *} *$ & & $\rho=0.1406^{* * *}$ & \\
\hline & $(0.0270)$ & & $(0.0272)$ & \\
\hline & $\mathrm{N}$ obs: 12,164 & & $\mathrm{~N}$ obs: 12,164 & \\
\hline & $\mathrm{N}$ firms: 3064 & & $\mathrm{~N}$ firms: 3064 & \\
\hline
\end{tabular}

Note: $* p<0.10, * * p<0.05, * * * p<0.01$. The regressions are estimated on our service firms sample for the period 1999-2010. Robust firm-clustered standard errors in parentheses. "Tech" and "Export" are two dummies that indicate firms invest in technology and export services respectively. The continuous variables are in natural logarithm except age and size. The "initial values" include the initial value of internal funding, external financing through banks, external financing through equity markets, other finance, size, imported services, imported capital goods and lnTFP 
Table 8. Exporting and investing in technology: Marginal effects from dynamic bivariate probit estimations.

\begin{tabular}{|c|c|c|c|c|c|c|}
\hline \multirow[t]{2}{*}{ Variables } & (1) & (2) & (3) & (4) & (5) & (6) \\
\hline & Tech & Export & Tech & Export & Tech & Export \\
\hline \multirow[t]{2}{*}{ internal funding $\mathrm{t}_{-1}$} & $0.0227 * * *$ & $0.0096^{* * * *}$ & $0.0167 * * *$ & $0.0080 * * *$ & $0.0136^{* * *}$ & $0.0082 * * *$ \\
\hline & $(0.002)$ & $(0.001)$ & $(0.003)$ & $(0.001)$ & $(0.003)$ & $(0.002)$ \\
\hline \multirow{2}{*}{$\begin{array}{l}\text { external financing } \\
\text { through banks }\end{array}$} & $0.0075 * * *$ & 0.0000 & $0.0105 * * *$ & -0.0000 & $0.0085 * * *$ & -0.0019 \\
\hline & $(0.002)$ & $(0.001)$ & $(0.002)$ & $(0.001)$ & $(0.003)$ & $(0.002)$ \\
\hline \multirow{2}{*}{$\begin{array}{l}\text { external financing } \\
\text { through equity } \\
\text { markets }_{\mathrm{t}-1}\end{array}$} & -0.0009 & -0.0001 & $0.0081^{*}$ & 0.0022 & 0.0050 & 0.0017 \\
\hline & $(0.002)$ & $(0.001)$ & $(0.004)$ & $(0.002)$ & $(0.005)$ & $(0.003)$ \\
\hline \multirow[t]{2}{*}{ other finance $\mathrm{t}_{\mathrm{t}-1}$} & $0.0159 * * *$ & $0.0020 *$ & $0.0191 * * *$ & $0.0032 * *$ & $0.0155^{* * *}$ & 0.0034 \\
\hline & $(0.002)$ & $(0.001)$ & $(0.003)$ & $(0.002)$ & $(0.004)$ & $(0.002)$ \\
\hline \multirow[t]{2}{*}{$\operatorname{Tech}_{\mathrm{t}-1}$} & $0.3183 * * *$ & $0.0180 * * *$ & $0.3150 * * *$ & $0.0172 * * *$ & $0.3397 * * *$ & $0.0138 * * *$ \\
\hline & $(0.007)$ & $(0.004)$ & $(0.007)$ & $(0.004)$ & $(0.008)$ & $(0.005)$ \\
\hline \multirow[t]{2}{*}{ Export $_{t-1}$} & $0.0600 * * *$ & $0.2519 * * *$ & $0.0566 * * *$ & $0.2502 * * *$ & $0.0345 * * *$ & $0.2972 * * *$ \\
\hline & $(0.008)$ & $(0.004)$ & $(0.008)$ & $(0.004)$ & $(0.010)$ & $(0.005)$ \\
\hline \multirow[t]{2}{*}{ age $_{t-1}$} & $-0.0019 * * *$ & $-0.0003 * * *$ & $-0.0018 * * *$ & $-0.0003 * * *$ & $-0.0020 * * *$ & -0.0002 \\
\hline & $(0.000)$ & $(0.000)$ & $(0.000)$ & $(0.000)$ & $(0.000)$ & $(0.000)$ \\
\hline \multirow[t]{2}{*}{$\operatorname{size}_{t-1}$} & 0.0002 & $-0.0025 * *$ & 0.0035 & -0.0015 & $0.0066^{* *}$ & -0.0015 \\
\hline & $(0.001)$ & $(0.001)$ & $(0.002)$ & $(0.001)$ & $(0.003)$ & $(0.002)$ \\
\hline \multirow[t]{2}{*}{ imported services $_{\mathrm{t}-1}$} & -0.0011 & $0.0126^{* * * *}$ & -0.0025 & $0.0092 * * *$ & -0.0022 & $0.0133 * * *$ \\
\hline & $(0.003)$ & $(0.002)$ & $(0.004)$ & $(0.003)$ & $(0.005)$ & $(0.004)$ \\
\hline \multirow[t]{2}{*}{ imported capital goods t-1 $_{\text {im }}$} & -0.0001 & $0.0066^{* * * *}$ & -0.0022 & $0.0038^{*}$ & 0.0008 & $0.0052 *$ \\
\hline & $(0.004)$ & $(0.002)$ & $(0.005)$ & $(0.002)$ & $(0.005)$ & $(0.003)$ \\
\hline \multirow[t]{2}{*}{$\operatorname{lnTFP} P_{t-1}$} & & & & & 0.0026 & 0.0026 \\
\hline & & & & & $(0.004)$ & $(0.003)$ \\
\hline initial values & & & yes & yes & yes & yes \\
\hline ownership dummies & yes & yes & yes & yes & yes & yes \\
\hline year dummies & yes & yes & yes & yes & yes & yes \\
\hline \multirow[t]{5}{*}{ industry dummies } & yes & yes & yes & yes & yes & yes \\
\hline & \multicolumn{2}{|c|}{$\rho=0.2084 * * *$} & \multicolumn{2}{|c|}{$\rho=0.2056^{* * *}$} & \multicolumn{2}{|c|}{$\rho=0.1406^{* * *}$} \\
\hline & \multicolumn{2}{|l|}{$(0.0232)$} & \multicolumn{2}{|l|}{$(0.0234)$} & \multicolumn{2}{|l|}{$(0.0272)$} \\
\hline & \multicolumn{2}{|c|}{$\mathrm{N}$ obs: 18,705} & \multicolumn{2}{|c|}{$\mathrm{N}$ obs: 18,705} & \multicolumn{2}{|c|}{$\mathrm{N}$ obs: 12,164} \\
\hline & \multicolumn{2}{|c|}{$\mathrm{N}$ firms: 4434} & \multicolumn{2}{|c|}{ N firms: 4434} & \multicolumn{2}{|c|}{ N firms: 3064} \\
\hline
\end{tabular}

Note: $* p<0.10, * * p<0.05, * * * p<0.01$. The regressions are estimated on our service firms sample for the period 1999-2010. Robust firm-clustered standard errors in parentheses. "Tech" and "Export" are two dummies that indicate firms invest in technology and export services respectively. The continuous variables are in natural logarithm except age and size. The "initial values" include the initial value of internal funding, external financing through banks, external financing through equity markets, other finance, size, imported services and imported capital goods, and also lnTFP for column (5) and (6) 
Table 9. Role of financing sources on exporting and investing in technology: Controlling for potential reverse causality. Marginal effects from dynamic bivariate probit estimations.

\begin{tabular}{|c|c|c|}
\hline \multirow[t]{2}{*}{ Variables } & (1) & (2) \\
\hline & Tech & Export \\
\hline \multirow[t]{2}{*}{ internal funding $\mathrm{t}-1$} & $0.0156^{* * *}$ & $0.0057 * *$ \\
\hline & $(0.004)$ & $(0.002)$ \\
\hline \multirow[t]{2}{*}{ external financing through banks ${ }_{t-1}$} & $0.0109 * * *$ & 0.0003 \\
\hline & $(0.003)$ & $(0.002)$ \\
\hline \multirow[t]{2}{*}{ external financing through equity markets ${ }_{t-1}$} & 0.0045 & 0.0041 \\
\hline & $(0.006)$ & $(0.003)$ \\
\hline \multirow[t]{2}{*}{ other finance ${ }_{t-1}$} & $0.0153 * * *$ & 0.0008 \\
\hline & $(0.004)$ & $(0.002)$ \\
\hline \multirow[t]{2}{*}{$\operatorname{Tech}_{\mathrm{t}-1}$} & $0.3253 * * *$ & $0.0174 * * *$ \\
\hline & $(0.007)$ & $(0.004)$ \\
\hline \multirow[t]{2}{*}{ Export $_{\mathrm{t}-1}$} & $0.0589 * * *$ & 0.2527 *** \\
\hline & $(0.009)$ & $(0.004)$ \\
\hline \multirow[t]{2}{*}{ age $t-1$} & $-0.0019 * * *$ & $-0.0003 * * *$ \\
\hline & $(0.000)$ & $(0.000)$ \\
\hline \multirow[t]{2}{*}{ size $t-1$} & $0.0045^{*}$ & -0.0013 \\
\hline & $(0.002)$ & $(0.001)$ \\
\hline \multirow[t]{2}{*}{ imported services ${ }_{t-1}$} & -0.0014 & $0.0099 * * *$ \\
\hline & $(0.004)$ & $(0.003)$ \\
\hline \multirow[t]{6}{*}{ imported capital goods $\mathrm{t}-1$} & -0.0008 & $0.0045^{* *}$ \\
\hline & $(0.005)$ & $(0.002)$ \\
\hline & $\rho=0.2058 * * *$ & \\
\hline & $(0.0234)$ & \\
\hline & N obs: 18,705 & \\
\hline & N firms: 4434 & \\
\hline
\end{tabular}

Note: $* \mathrm{p}<0.10, * * \mathrm{p}<0.05, * * * \mathrm{p}<0.01$. The regressions are estimated on our service firms sample for the period 1999-2010. Average marginal effects are presented in the table. Robust firm-clustered standard errors in parentheses. "Tech" and "Export" are two dummies that indicate firms invest in technology and export services respectively. The continuous variables are in natural logarithm except age and size. The financing sources variables, namely, internal funding, external financing through banks, external financing through equity markets, other finance, are instrumented with their t-3 lagged values. Initial values of internal funding, external financing through banks, external financing through equity markets, other finance, size, imported services and imported capital goods are included in the estimation, and ownership, industry and time dummies are also controlled 
Table 10. Role of financing sources on exporting and investing in technology: dynamic linear probability model.

\begin{tabular}{|c|c|c|}
\hline \multirow[t]{2}{*}{ Variables } & (1) & \\
\hline & Tech & Export \\
\hline \multirow[t]{2}{*}{ internal funding $\mathrm{t}_{\mathrm{t}-1}$} & $0.0251 * * *$ & $0.0108 * * *$ \\
\hline & $(0.002)$ & $(0.001)$ \\
\hline \multirow[t]{2}{*}{ external financing through banks $\mathrm{t}_{\mathrm{t}-1}$} & $0.0088 * * *$ & 0.0001 \\
\hline & $(0.002)$ & $(0.001)$ \\
\hline \multirow[t]{2}{*}{ external financing through equity markets ${ }_{t-1}$} & -0.0010 & 0.0005 \\
\hline & $(0.002)$ & $(0.001)$ \\
\hline \multirow[t]{2}{*}{ other finance $\mathrm{t}_{-1}$} & $0.0167 * * *$ & $0.0021 * *$ \\
\hline & $(0.002)$ & $(0.001)$ \\
\hline \multirow[t]{2}{*}{$\mathrm{Tech}_{\mathrm{t}-1}$} & $0.4480 * * *$ & $0.0199 * * *$ \\
\hline & $(0.009)$ & $(0.005)$ \\
\hline \multirow[t]{2}{*}{ Export $_{\mathrm{t}-1}$} & $0.0684 * * *$ & $0.7942 * * *$ \\
\hline & $(0.009)$ & $(0.007)$ \\
\hline \multirow[t]{2}{*}{ age $_{t-1}$} & $-0.0016^{* * *}$ & $-0.0002 * *$ \\
\hline & $(0.000)$ & $(0.000)$ \\
\hline \multirow[t]{2}{*}{$\operatorname{size}_{\mathrm{t}-1}$} & 0.0007 & $-0.0019 * *$ \\
\hline & $(0.001)$ & $(0.001)$ \\
\hline \multirow[t]{2}{*}{ imported services $_{\mathrm{t}-1}$} & -0.0018 & \\
\hline & $(0.003)$ & \\
\hline \multirow[t]{2}{*}{ imported capital goods $\mathrm{s}_{\mathrm{t}-1}$} & & $0.0132 * * *$ \\
\hline & & $(0.002)$ \\
\hline \multirow[t]{2}{*}{ constant } & $0.2588 * * *$ & 0.0177 \\
\hline & $(0.036)$ & $(0.031)$ \\
\hline ownership dummies & yes & yes \\
\hline year dummies & yes & yes \\
\hline \multirow[t]{5}{*}{ industry dummies } & yes & yes \\
\hline & $\rho=0.0679 * * *$ & \\
\hline & $(0.0089)$ & \\
\hline & N obs: 18,705 & \\
\hline & $\mathrm{N}$ firms: 4434 & \\
\hline
\end{tabular}

Note: $* \mathrm{p}<0.10, * * \mathrm{p}<0.05$, *** $\mathrm{p}<0.01$. The regressions are estimated using SURs on our service firms sample for the period 1999-2010. Robust firm-clustered standard errors in parentheses. "Tech" and "Export" are two dummies that indicate firms invest in technology and export services respectively. The continuous variables are in natural logarithm except age and size 


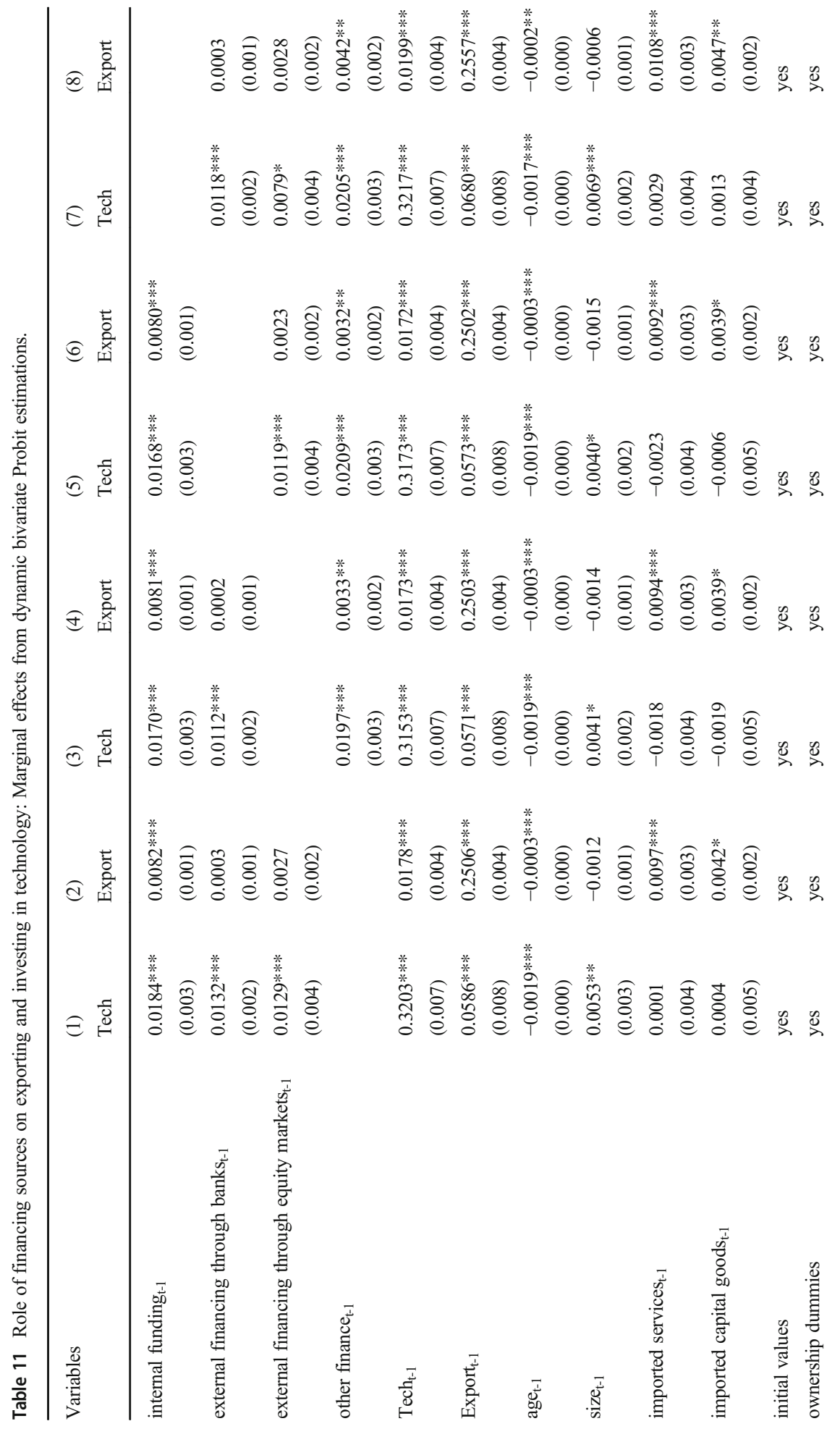




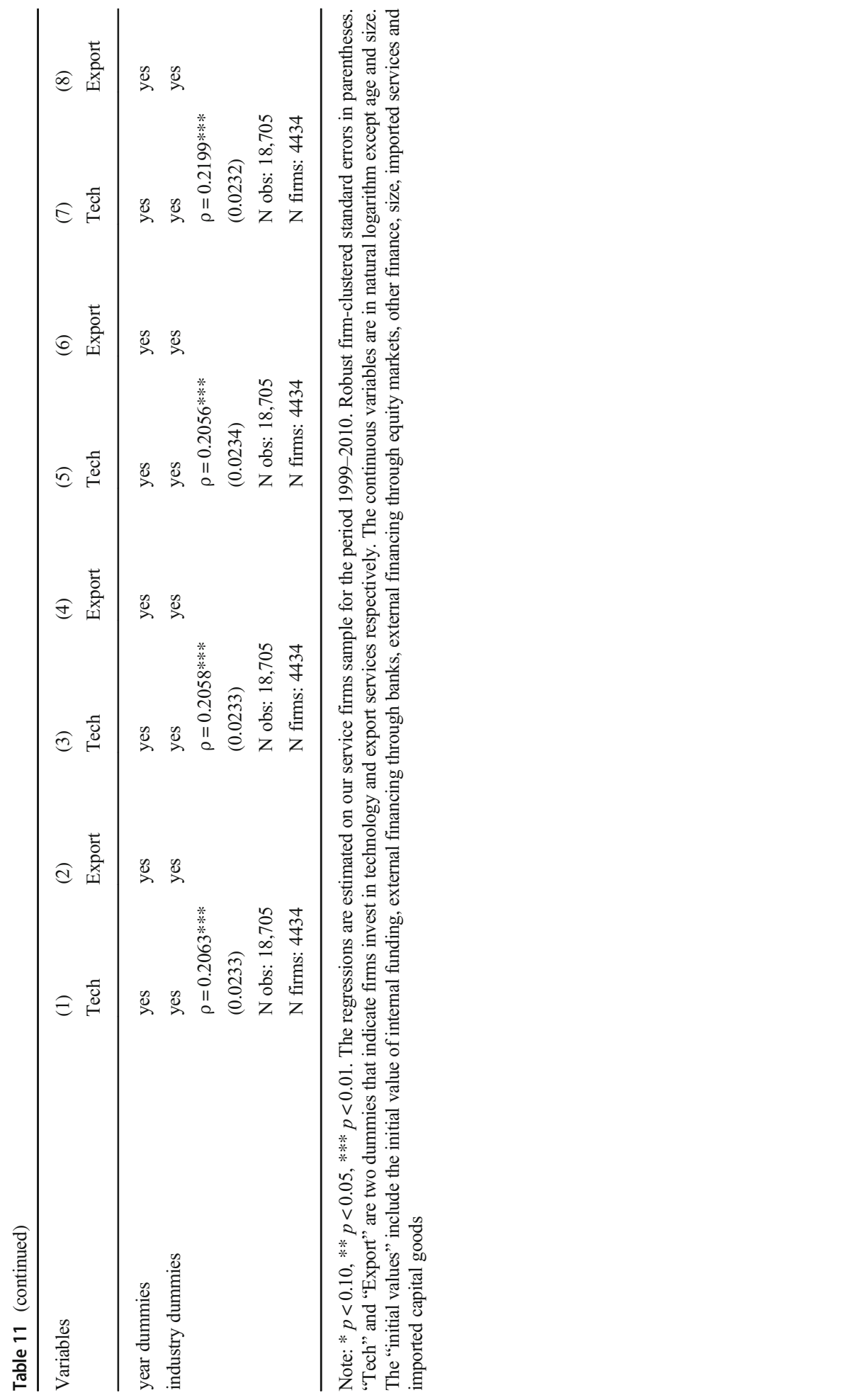


Open Access This article is licensed under a Creative Commons Attribution 4.0 International License, which permits use, sharing, adaptation, distribution and reproduction in any medium or format, as long as you give appropriate credit to the original author(s) and the source, provide a link to the Creative Commons licence, and indicate if changes were made. The images or other third party material in this article are included in the article's Creative Commons licence, unless indicated otherwise in a credit line to the material. If material is not included in the article's Creative Commons licence and your intended use is not permitted by statutory regulation or exceeds the permitted use, you will need to obtain permission directly from the copyright holder. To view a copy of this licence, visit http://creativecommons.org/licenses/by/4.0/.

\section{References}

Aghion P, Askenazy P, Berman N, Cette G, Eymard L (2012) Credit constraints and the cyclicality of R\&D investment: evidence from France. J Eur Econ Assoc 10(5):1001-1024

Allen F, Chakrabarti R, De S, Qian JQ, Qian M (2012) Financing firms in India. J Financ Intermed 21(3):409445

Altomonte C, Gamba S, Mancusi ML, Vezzulli A (2015) R\&D investments, financing constraints, Exporting and Productivity Economics of Innovation and New Technology, 1-21

Atkeson A, Burstein AT (2010) Innovation, firm dynamics, and international trade. J Polit Econ 118(3):433484

Aw BY, Roberts MJ, Winston T (2007) Export market participation, Investments in R\&D and worker training, and the evolution of firm productivity. World Economy 30(1):83-104

Aw BY, Roberts MJ, Xu DY (2008) R\&D investments, exporting, and the evolution of firm productivity. Am Econ Rev 98(2):451-456

Aw BY, Roberts MJ, Xu DY (2011) R\&D investment, exporting, and productivity dynamics. Am Econ Rev 101(4):1312-1344

Ayyagari M, Demirgüç-Kunt A, Maksimovic V (2011) Firm innovation in emerging markets: the role of finance, governance, and competition. J Financ Quant Anal 46(6):1545-1580

Bas M (2012) Input-trade liberalization and firm export decisions: evidence from Argentina. J Dev Econ 97(2):481-493

Brown JR, Fazzari SM, Petersen BC (2009) Financing innovation and growth: cash flow, external equity, and the 1990s R\&D boom. J Financ 64:151-185

Brown JR, Martinsson G, Petersen BC (2012) Do financing constraints matter for R\&D? Eur Econ Rev 56(8): 1512-1529

Bustos P (2011) Trade liberalization, exports, and technology upgrading: evidence on the impact of MERCOSUR on Argentinian firms. Am Econ Rev 101(1):304-340

Canepa A, Stoneman P (2007) Financial constraints to innovation in the UK: evidence from CIS2 and CIS3. Oxf Econ Pap 60:711-730

Chaney T (2016) Liquidity constrained exporters. J Econ Dyn Control 72:141-154

Costantini J, Melitz M (2007) The dynamics of firm-level adjustment to trade liberalization. The organization of firms in a global economy 107:141

Du J, Girma S (2012) Firm size, source of finance, and growth - evidence from China. Int J Econ Bus 19:397419

Das S, Roberts MJ, Tybout JR (2007) Market entry costs, producer heterogeneity, and export dynamics. Econometrica 75(3):837-873

Eichengreen B, Gupta P (2013) The two waves of service-sector growth. Oxf Econ Pap 65(1):96-123

Egger P, Kesina M (2013) Financial constraints and exports: evidence from Chinese firms. CESifo Economic Studies 59:676-706

Feng L, Li Z, Swenson DL (2016) The connection between imported intermediate inputs and exports: evidence from Chinese firms. J Int Econ 101:86-101

Filippini M, Greene WH, Kumar N, Martinez-Cruz AL (2018) A note on the different interpretation of the correlation parameters in the bivariate Probit and the recursive bivariate Probit. Econ Lett 167:104-107

Foster-McGregor N, Isaksson A, Kaulich F (2016) Importing, productivity and absorptive capacity in subSaharan African manufacturing and services firms. Open Econ Rev 27(1):87-117

Francois J, Hoekman B (2010) Services trade and policy. J Econ Lit 48(3):642-692 
Girma S, Vencappa D (2014) Financing sources and firm level productivity growth: evidence from Indian manufacturing. J Prod Anal, 1-10

Gorodnichenko Y, Schnitzer M (2013) Financial constraints and innovation: why poor countries Don't catch up. J Eur Econ Assoc 11(5):1115-1152

Greene WH (2012) Econometric analysis. Seventh Edition. Pearson

Gullstrand J, Olofsdotter K, Thede S (2016) Importers, exporters and multinationals: exploring the hierarchy of international linkages. Open Econ Rev 27(3):495-514

Hall BH, Lerner J (2010) The financing of R\&D and innovation. In H. H. Bronwyn \& R. Nathan (Eds.), handbook of the economics of innovation (Vol. volume 1, pp. 609-639): North-Holland

Hogan T, Hutson E (2005) Capital structure in new technology-based firms: evidence from the Irish software sector. Glob Financ J 15(3):369-387

Kerr WR, Nanda R (2015) Financing Innovation. Annual Review of Financial Economics 7(1):445-462

Lancheros S, Demirel P (2012) Does finance play a role in exporting for service firms? Evidence from India. World Econ 35(1):44-60

Levinsohn J, Petrin A (2003) Estimating production functions using inputs to control for unobservables. Review of Economic Studies 70(2):317-341

Lileeva A, Trefler D (2010) Improved access to foreign markets raises plant-level productivity...for some plants. Q J Econ 125(3):1051-1099

Mancusi ML, Vezzulli A, Frazzoni S, Rotondi Z, Sobrero M (2018) Export and innovation in small and medium enterprises: the role of concentrated Bank borrowing. Economica 85(337):177-204

Máñez JA, Rochina-Barrachina ME, Sanchis-Llopis JA, Vicente Ó (2014) Financial constraints and R\&D and exporting strategies for Spanish manufacturing firms. Ind Corp Chang 23(6):1563-1594

Manova K (2013) Credit constraints, heterogeneous firms, and international trade. Rev Econ Stud 80:711-744

Melitz MJ (2003) The impact of trade on intra-industry reallocations and aggregate industry productivity. Econometrica 71(6):1695-1725

Minetti R, Zhu SC (2011) Credit constraints and firm exports: microeconomic evidence from Italy. J Int Econ 83:109-125

Roberts MJ, Tybout JR (1997) The decision to export in Colombia: an empirical model of entry with sunk costs. Am Econ Rev 87(4):545-564

Roodman D (2011) Fitting fully observed recursive mixed-process models with cmp. Stata J 11(2):159-206

Sahoo P, Dash RK (2017) What drives India's surge in service exports? World Econ 40(2):439-461

Silva F, Carreira C (2016) The role of financial constraints in the services sector: how different is it from manufacturing? Notas Económicas(43), 21-41

Sirilli G, Evangelista R (1998) Technological innovation in services and manufacturing: results from Italian surveys. Res Policy 27(9):881-899

Wagner J (2014) Credit constraints and exports: a survey of empirical studies using firm-level data. Ind Corp Chang 23(6):1477-1492

Wagner J (2019) Access to finance and exports - comparable evidence for small and medium enterprises from industry and services in 25 European countries. Open Econ Rev 30(4):739-757

Wooldridge JM (2005) Simple solutions to the initial conditions problem in dynamic, nonlinear panel data models with unobserved heterogeneity. J Appl Econ 20(1):39-54

Zahler A, Iacovone L, Mattoo A (2014) Trade and innovation in services: evidence from a developing economy. World Econ 37(7):953-979

Zellner A (1962) An efficient method of estimating seemingly unrelated regressions and tests for aggregation Bias. J Am Stat Assoc 57(298):348-368

Zellner A (1963) Estimators for seemingly unrelated regression equations: some exact finite sample results. J Am Stat Assoc 58(304):977-992

Zellner A, Huang DS (1962) Further properties of efficient estimators for seemingly unrelated regression equations. Int Econ Rev 3(3):300-313

Publisher's Note Springer Nature remains neutral with regard to jurisdictional claims in published maps and institutional affiliations. 